\title{
KORELASI POLARISASI MAGNET Z/H UNTUK IDENTIFIKASI PREKURSOR GEMPA DI SEKITAR PELABUHAN RATU
}

\author{
Asep Saepul Ahyar ${ }^{1, \text { a) }}$, Bambang Sunardi ${ }^{2, b)}$ \\ ${ }^{1}$ Jurusan Fisika, Fakultas Sains dan Teknologi UIN Sunan Gunung Djati, \\ Jl. A.H. Nasution 105, Bandung, 40614. \\ ${ }^{2}$ Puslitbang BMKG, Jl. Angkasa 1 No. 2 Kemayoran, Jakarta 10720. \\ Email: a)asepulahyar@gmail.com, b)b.sunardi@gmail.com
}

\begin{abstract}
Abstrak
Efek seismo-elektromagnetik yang berlangsung dalam rentang frekuensi luas yang mendahului gempa telah banyak dilaporkan dalam beberapa penelitian sebelumnya. Efek tersebut diharapkan dapat dimanfaatkan dalam mitigasi bencana gempa. Penelitian ini membahas penerapan metode korelasi polarisasi magnet komponen $\mathrm{Z} / \mathrm{H}$ untuk mengidentifikasi prekursor gempa di sekitar Pelabuhan Ratu. Data yang dipergunakan adalah data magnet tiga komponen selama 31 hari sebelum kejadian gempa. Identifikasi anomali geomagnet dilakukan dengan menerapkan metode korelasi polarisasi magnet $\mathrm{Z} / \mathrm{H}$ untuk menghitung rasio Simpangan koefisien korelasi (Skk) dengan Deviasi standar simpangan koefisien korelasi (Dskk). Ambang batas anomali adalah -1. Nilai Skk/Dskk $<-1$ mengindikasikan adanya anomali geomagnet. Kemunculan badai magnetik yang mempengaruhi anomali geomagnet dievaluasi menggunakan Disturbance storm time index (indeks Dst). Hasil penerapan metode korelasi polarisasi magnet Z/H pada lima kasus gempa di sekitar Pelabuhan Ratu dari Januari - Maret 2017 dengan magnitudo $M>4$ dan memenuhi radius zona manisfestasi prekursor menunjukkan kemunculan anomali geomagnet yang dikategorikan sebagai prekursor gempa. Kemunculan anomali geomagnet berkisar antara 16 - 2 hari sebelum gempa terjadi.
\end{abstract}

Kata-kata kunci: korelasi, geomagnet, prekursor gempa, Pelabuhan Ratu.

\begin{abstract}
Seismo-electromagnetic effects occurring in wide frequency range that preceded earthquake have been widely reported in several previous studies. The effect is expected to be utilized in earthquake disaster mitigation. This study discusses application of magnetic polarization correlation method of $\mathrm{Z} / \mathrm{H}$ component to identify earthquake precursors around Pelabuhan Ratu. Data used are three components magnet data for 31 days before earthquake events. Identification of magnetic anomaly was done by applying the magnetic polarization $\mathrm{Z} / \mathrm{H}$ method to calculate correlation coefficient ratio (Skk) with standard deviation of correlation coefficient deviation (Dskk). The anomaly threshold is -1 . Less than -1 of Skk / Dskk values indicate geomagnetic anomaly. The emergence of geomagnetic storms that affect geomagnetic anomalies is evaluated using the Disturbance storm time index (Dst index). The result of application of $\mathrm{Z} / \mathrm{H}$ magnet polarization correlation method in five earthquake cases around Pelabuhan Ratu from January to March 2017 with magnitude M > 4 and meeting precursor manifestation radius zone showed the occurrence of geomagnetic anomalies categorized as earthquake precursors. The appearance of geomagnetic anomalies ranged from 16 to 2 days before earthquakes occurred.
\end{abstract}

Keywords: correlation, geomagnetic, earthquake precursor, Pelabuhan Ratu. 


\section{PENDAHULUAN}

Fenomena anomali elektromagnetik dalam rentang frekuensi yang luas telah banyak dilaporkan sebelum kejadian gempa [1]. Fenomena tersebut muncul dengan jelas antara lain sebelum kejadian gempa Armenia, 8 Desember 1988 (M 6.9), gempa Loma Prieta 18 Oktober 1989 (M 7.1) serta gempa Guam 8 Agustus 1993 (M 8) [2]. Efek tersebut diharapkan dapat dimanfaatkan dalam upaya mitigasi bencana gempa. Hipotesis yang berkembang menjelaskan hubungan mengenai fenomena tersebut dalam sistem ionosfer-atmosfer dan litosfer. Sebelum terjadinya gempa akan terjadi akumulasi energi di litosfer hingga terjadi retakan mikro (microfracturing) yang mengakibatkan lepasnya emisi Ultra Low Frequency (ULF) dan perubahan fisis lainnya sebagaimana ditunjukkan pada GAMBAR 1 [3].

Gempa berkaitan erat dengan proses pelepasan energi tekanan (stress) batuan yang terakumulasi sebelumnya, yang terjadi karena proses pergerakan relatif lempeng-lempeng tektonik satu dengan lainnya. Saat materi mengalami tekanan maka akan mengalami beberapa perubahan seperti sifat kemagnetan, sifat radio aktif, kepadatan, kandungan air, kandungan elektron, suhu dan sebagainya. Perubahan tersebut secara teori dapat di monitor. Perubahan tekanan batuan juga menghasilkan aliran elektrokinetik yang disebabkan oleh deposit silika pada batuan sehingga menghasilkan aliran gangguan magnet bumi [4].

Salah satu penelitian yang sedang berkembang saat ini adalah mempelajari gejala-gejala awal sebelum gempa terjadi (prekursor). Beberapa peneliti meyakini bahwa sebelum kejadian gempa akan didahului dengan perubahan-perubahan parameter fisis yang dapat di monitor. Penelitian prekursor gempa telah dilakukan melalui berbagai pengamatan antara lain pengamatan parameter Total Electron Content (TEC). Hasil pengamatan memperlihatkan kemunculan anomali TEC terkait dengan proses persiapan gempa $[5,6]$. Studi menggunakan parameter elektromagnetik (EM) menunjukkan anomali EM sebelum kejadian gempa di sekitar Pelabuhan Ratu [7]. Demikian juga pengamatan simultan parameter EM dan emisi gas radon sebelum 3 kasus gempa di sekitar Pelabuhan Ratu tahun 2014 menemukan adanya anomali pada kedua parameter yang diamati kurang dari 50 hari sebelum kejadian gempa [8]. Berbagai temuan tersebut memperkuat dugaan bahwa sebelum kejadian gempa akan didahului dengan kemunculan tanda-tanda awal (prekursor) gempa.

Makalah ini membahas penerapan metode korelasi polarisasi magnet komponen $\mathrm{Z} / \mathrm{H}$ untuk mengidentifikasi prekursor gempa di sekitar Pelabuhan Ratu dalam rentang waktu Januari - Maret 2017. Metode korelasi dengan menghitung rasio Simpangan koefisien korelasi dengan Deviasi standar (Skk/Dskk) telah diterapkan untuk mengidentifikasi kemunculan anomali TEC sebelum gempa $[5,6,9,10,11]$, namun penerapan metode tersebut untuk data magnet bumi belum dilakukan.

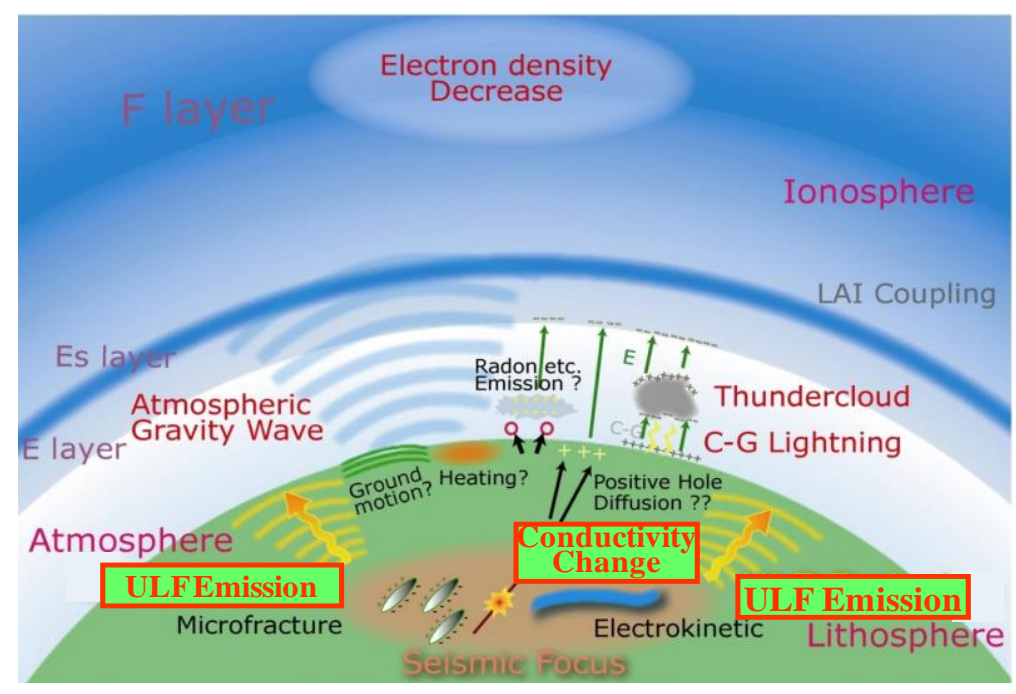

GAMBAR 1. Konsep Litosphere Atmosphere Ionosphere (LAI) coupling [3]. 


\section{METODE PENELITIAN}

Tahapan penelitian dimulai dengan pemilihan stasiun magnet bumi dan kasus gempa yang akan diteliti. Dalam penelitian ini, data yang dipergunakan adalah data magnet bumi dari stasiun observasi di Pelabuhan Ratu. Kasus gempa yang akan diteliti diperoleh dari katalog BMKG [12], dengan batasan kejadian gempa disekitar Pelabuhan Ratu pada periode Januari - Maret 2017, magnitudo (M) $>$ 4. Kasus gempa yang diteliti juga ditentukan berdasarkan perhitungan batasan jarak fungsi magnitudo [13]. Radius zona manisfestasi prekursor yang efektif bergantung pada magnitudo gempa dan dapat ditentukan berdasarkan rumusan empiris pada persamaan (1).

$$
R_{D}=10^{0.43 \times M_{L}}
$$

Dimana $R_{D}$ adalah radius strain dalam kilometer dan $M_{L}$ adalah magnitudo gempa lokal. Berdasarkan kriteria tersebut, dalam rentang waktu Januari - Maret 2017 tercatat ada lima kejadian gempa yang masuk dalam kriteria tersebut. Daftar gempa di sekitar Pelabuhan Ratu pada periode Januari - Maret 2017 dengan magnitudo > 4 dan memenuhi kriteria dalam persamaan (1) ditunjukkan pada TABEL 1.

Setelah diperoleh lima kasus gempa yang masuk zona manifestasi [13] selanjutnya dilakukan pengambilan data magnet bumi yang berada di arsip data BMKG. Data magnet bumi diambil selama 31 hari sebelum kejadian gempa yang hendak diteliti dengan asumsi bahwa 1 bulan sebelum terjadinya gempa utama, para peneliti meyakini adanya perubahan fisis yang terjadi seperti diterangkan dalam konsep LAI coupling [3] terutama perubahan sifat kemagnetan sebagai tanda awal terjadinya gempa. Proses gempa berasal dari pergerakan lempeng bumi, dengan demikian medan magnet bumi yang di analisis adalah medan magnet utama. Adanya gangguan medan magnet luar seperti halnya badai matahari perlu diketahui sehingga mengurangi kesalahan dalam analisis. Untuk mengetahui adanya gangguan medan magnet luar akibat badai matahari digunakan data Disturbance storm time index (indeks DST) yang dapat diperoleh secara real time [14].

Data yang diperlukan adalah data magnet bumi tiga komponen (X, Y, Z) dari stasiun observasi Pelabuhan Ratu. Data tiga komponen tersebut merupakan komponen arah medan magnet bumi yang terukur oleh Magnetometer, dimana X merupakan medan magnet bumi komponen horisontal yang searah dengan arah utara geografis, Y merupakan medan magnet bumi komponen horisontal yang searah dengan arah timur geografis, serta $\mathrm{Z}$ merupakan medan magnet bumi komponen vertikal. Medan magnet bumi komponen horisontal biasa disebut sebagai komponen H. Selanjutnya memeriksa kualitas data yang diperoleh dengan mengidentifikasi noise pada data. Untuk mengurangi noise akibat aktivitas manusia, data magnet bumi yang dipergunakan dibatasi hanya pada jam 15.00 22.00 UTC (jam 23.00 - 03.00 WIB)

Polarisasi data magnet $\mathrm{Z} / \mathrm{H}$ ditentukan dari data magnet bumi dengan resolusi temporal 1 jam. Untuk mendapatkan data magnet resolusi 1 jam dilakukan dengan merata-ratakan data magnet bumi resolusi 1 menit selama 1 jam. Identifikasi anomali geomagnet dilakukan dengan menerapkan metode korelasi polarisasi magnet $\mathrm{Z} / \mathrm{H}$, dengan menghitung rasio Simpangan koefisien korelasi (Skk) dengan Deviasi standar simpangan koefisien korelasi (Dskk). Hasil perhitungan Skk/Dskk di plot menjadi grafik Skk/Dskk selama 31 hari sebelum kejadian gempa.

TABEL 1. Daftar gempa di sekitar Pelabuhan Ratu, magnitudo > 4, periode Januari - Maret 2017 [12].

\begin{tabular}{ccccc}
\hline Tanggal & Bujur & Lintang & Kedalaman & Magnitudo \\
\hline $12-01-2017$ & 106.94 & -7.72 & 27 & 4.8 \\
$26-01-2017$ & 107.05 & -7.86 & 47 & 4.8 \\
$8-022017$ & 106.9 & -7.62 & 70 & 5 \\
$15-02-2017$ & 107.28 & -7.72 & 61 & 5.2 \\
$14-03-2017$ & 106.6 & -7.72 & 16 & 5 \\
\hline
\end{tabular}


Nilai threshold atau ambang batas anomali adalah -1. Nilai Skk/Dskk $<-1$ mengindikasikan adanya anomali geomagnet. Namun demikian perlu dilihat juga kemunculan badai matahari yang dapat mempengaruhi anomali geomagnet tersebut dengan cara melihat nilai Disturbance storm time index [14]. Indek Dst dipergunakan untuk monitoring aktivitas magnetik yang bersifat global yang terekam di daerah ekuator dan lintang rendah. Umumnya gangguan medan magnet atau badai magnet dinyatakan dengan nilai negatif yang menunjukkan penurunan medan magnet bumi [15]. Aktivitas badai magnetik dapat diklasifikasikan menjadi tiga, yaitu massive storm $<-300 \mathrm{nT}$, storm $<-50 \mathrm{nT}$, dan severe storm <-30 nT [16].

Onset time ditentukan dari waktu awal terjadinya anomali geomagnet (Skk/Dskk $<-1$ dan indeks Dst normal). Rentang waktu antara onset time dengan waktu gempa utama terjadi disebut dengan lead time. Secara garis besar tahap-tahap dalam penerapan metode korelasi rasio polarisasi magnet $\mathrm{Z} / \mathrm{H}$ untuk identifikasi prekursor gempa di sekitar Pelabuhan Ratu dapat dilihat pada diagram alir GAMBAR 2.

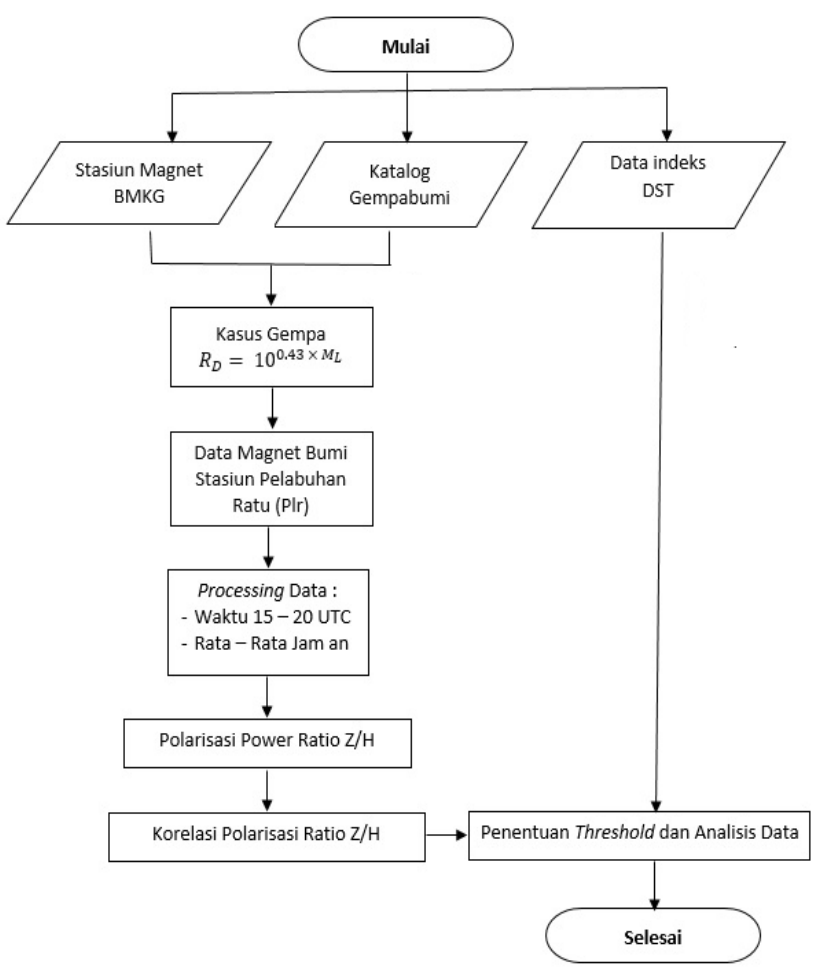

GAMBAR 2. Tahapan penelitian analisis korelasi rasio polarisasi magnet Z/H terkait gempa di sekitar Pelabuhan Ratu, Januari-Maret 2017, magnitudo $\mathrm{M}>4$.

\section{HASIL DAN PEMBAHASAN}

Hasil analisis metode korelasi berdasarkan rasio Simpangan koefisien korelasi dengan Deviasi standar simpangan koefisien korelasi (Skk/Dskk) terhadap waktu kejadian gempa menunjukkan gejala awal yang diduga berkaitan dengan gempa 12 Januari 2017. Anomali geomagnet ditemukan pada tanggal 26 Desember 2016 ditandai dengan nilai Skk/Dskk -2.1. Anomali geomagnet tersebut berulang pada tanggal 28, 30 dan 31 Desember 2016 ditandai dengan nilai Skk/Dskk -1.2, -1.6 dan 1.3. Anomali geomagnet juga dapat terjadi dikarenakan pengaruh medan magnet luar yang bersifat global, seperti halnya badai magnetik yang disebabkan oleh badai matahari. Untuk mengetahui hal tersebut perlu ditinjau nilai indeks Dst. Pada tanggal terjadinya anomali geomagnet tersebut tidak dijumpai adanya badai magnetik. Nilai indeks Dst pada tanggal anomali geomagnet relatif pada kisaran normal, sebagaimana diperlihatkan pada GAMBAR 3. Anomali yang terjadi muncul antara 16 hingga 12 hari sebelum gempa 12 Januari 2017. Anomali geomagnet yang muncul sebelum 
gempa sesuai dengan beberapa penelitian yang pernah dilakukan sebelumnya $[2,17,18]$. Perubahan medan magnet kemungkinan disebabkan oleh kemunculan ion-ion positif yang berasal dari microfracture di litosfer. Secara tidak langsung, hal tersebut menyebabkan perubahan medan magnet bumi yang terukur di permukaan.

Hasil analisis rasio Simpangan koefisien korelasi magnetik dengan Deviasi standar simpangan koefisien korelasi (Skk/Dskk) sebelum kejadian gempa tanggal 26 Januari 2017 (magnitudo 4.8), gempa 8 Februari 2017 (magnitudo 5), gempa 15 Februari 2017 (magnitudo 5.2), gempa 14 Maret 2017 (magnitudo 5), serta variasi nilai nilai indeks Dst nya masing-masing diperlihatkan pada GAMBAR $4-7$.

Nilai rasio simpangan koefisien korelasi (Skk) dengan deviasi standar (Dskk) data geomagnet sebelum gempa 26 Januari 2017 (M4.8) mengalami anomali pada tanggal 28, 30, 31 Desember 2016 serta 20 dan 21 Januari 2017. Nilai indeks Dst pada tanggal tersebut relatif normal, mengindikasikan tidak adanya badai magnetik dari luar (GAMBAR 4). Anomali geomagnet pada tanggal 28, 30, 31 Desember 2016 berkaitan dengan kejadian gempa tanggal 12 Januari 2017, sedangkan anomali geomagnet pada tanggal 20 dan 21 Januari 2017 kemungkinan merupakan prekursor gempa 26 Januari 2017. Anomali yang terjadi muncul 6 hingga 5 hari sebelum gempa 26 Januari 2017.
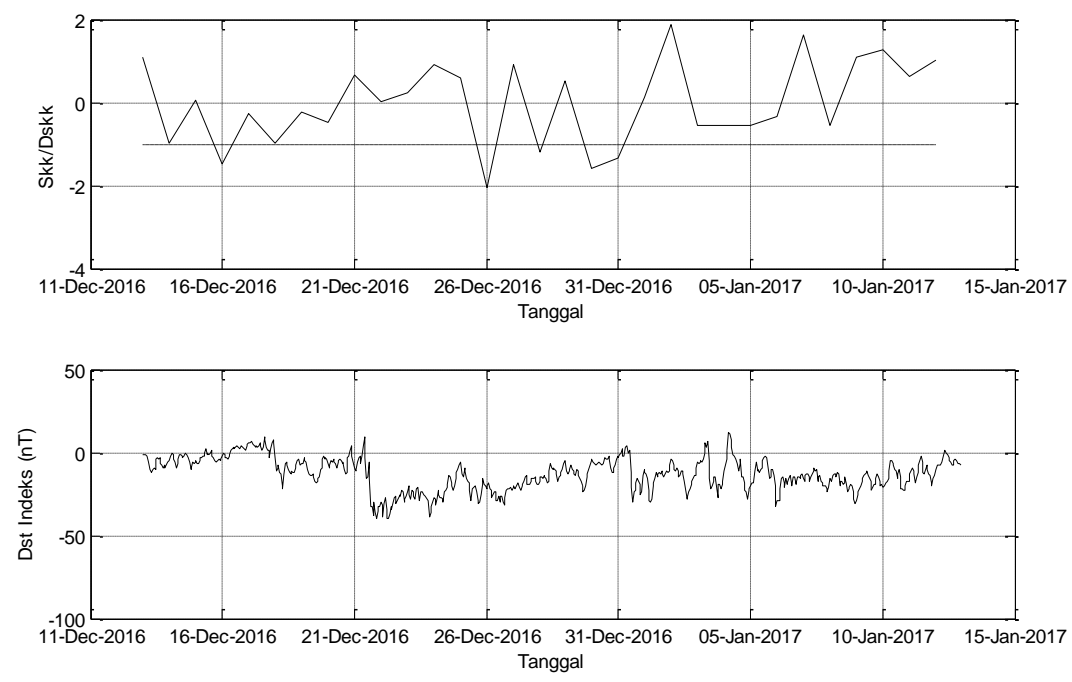

GAMBAR 3. Rasio simpangan koefisien korelasi (Skk) dengan deviasi standar (Dskk) data geomagnet serta indeks Dst sebelum gempa 12 Januari 2017 (M4.8).
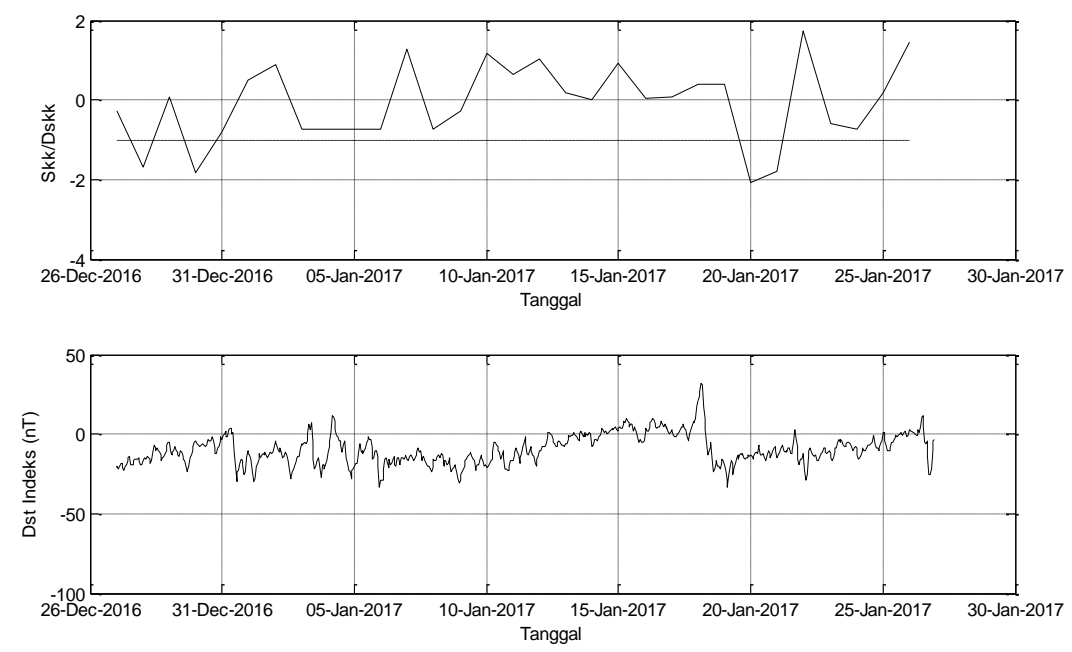

GAMBAR 4. Rasio simpangan koefisien korelasi (Skk) dengan deviasi standar (Dskk) data geomagnet serta indeks Dst sebelum gempa 26 Januari 2017 (M4.8). 
Untuk kasus gempa 8 Februari 2017 terlihat adanya anomali geomagnet yang menonjol pada tanggal 20 dan 21 Januari 2017 serta 7 Februari 2017 (GAMBAR 5). Nilai indeks Dst pada tanggal tersebut relatif normal. Dengan demikian anomali geomagnet yang muncul dua hari sebelum kejadian gempa tanggal 8 Februari 2017 dapat dipertimbangkan sebagai prekursor gempa.

Hasil analisis rasio Simpangan koefisien korelasi dengan Deviasi standar simpangan koefisien korelasi (Skk/Dskk) terhadap waktu kejadian gempa menunjukkan gejala awal yang diduga berkaitan dengan gempa 15 Februari 2017. Anomali geomagnet yang berkaitan dengan gempa terjadi pada tanggal 6 dan 9 Februari 2017 atau 8 dan 5 hari sebelum kejadian gempa utama (GAMBAR 6). Nilai indeks Dst pada tanggal tersebut relatif normal. Anomali yang terjadi tanggal 20 Januari 2017 berkaitan dengan kejadian gempa sebelumnya (gempa 8 Februari 2017).

Pada kasus gempa tanggal 14 Maret 2017 memperlihatkan adanya anomali geomagnet pada tanggal 19 dan 27 Februari 2017 serta pada tanggal 3, 4 dan 10 Maret 2017 (GAMBAR 7). Anomali yang terjadi pada 3 dan 4 Maret 2017 kemungkinan dikarenakan badai magnetik yang terjadi pada tanggal tersebut. Nilai indeks Dst pada tanggal tersebut menunjukkan adanya severe storm. Anomali yang terjadi pada tanggal 10 Maret 2017 atau 3 hari sebelum gempa 14 Maret 2017 dapat dipertimbangkan sebagai prekursor gempa.
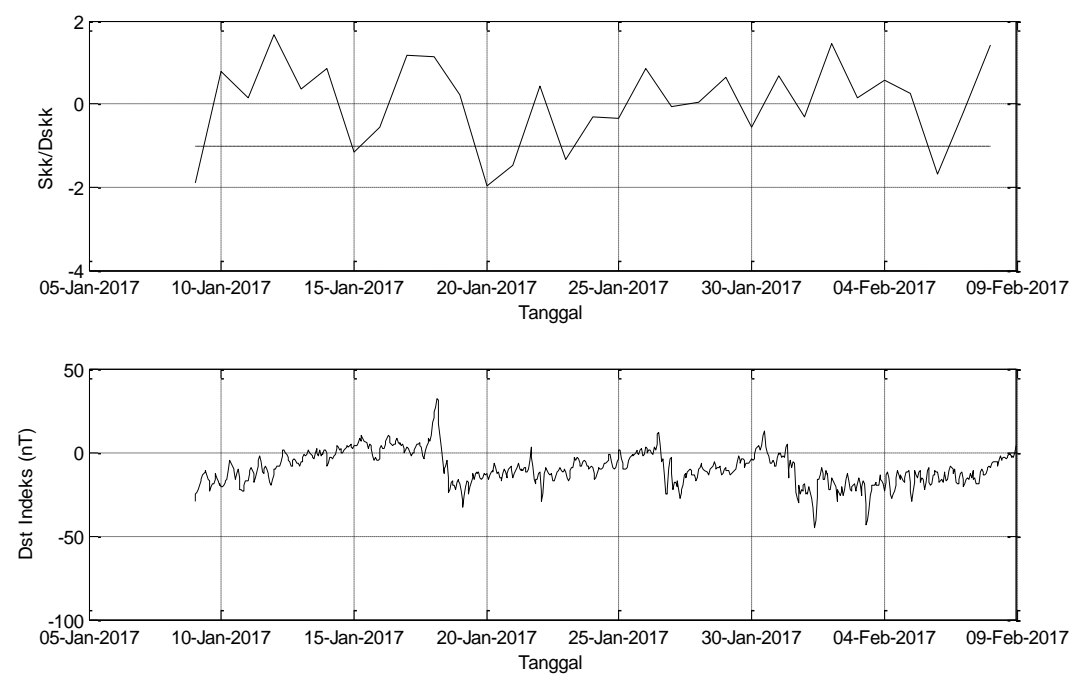

GAMBAR 5. Rasio simpangan koefisien korelasi (Skk) dengan deviasi standar (Dskk) data geomagnet serta indeks Dst sebelum gempa 8 Februari 2017 (M5).
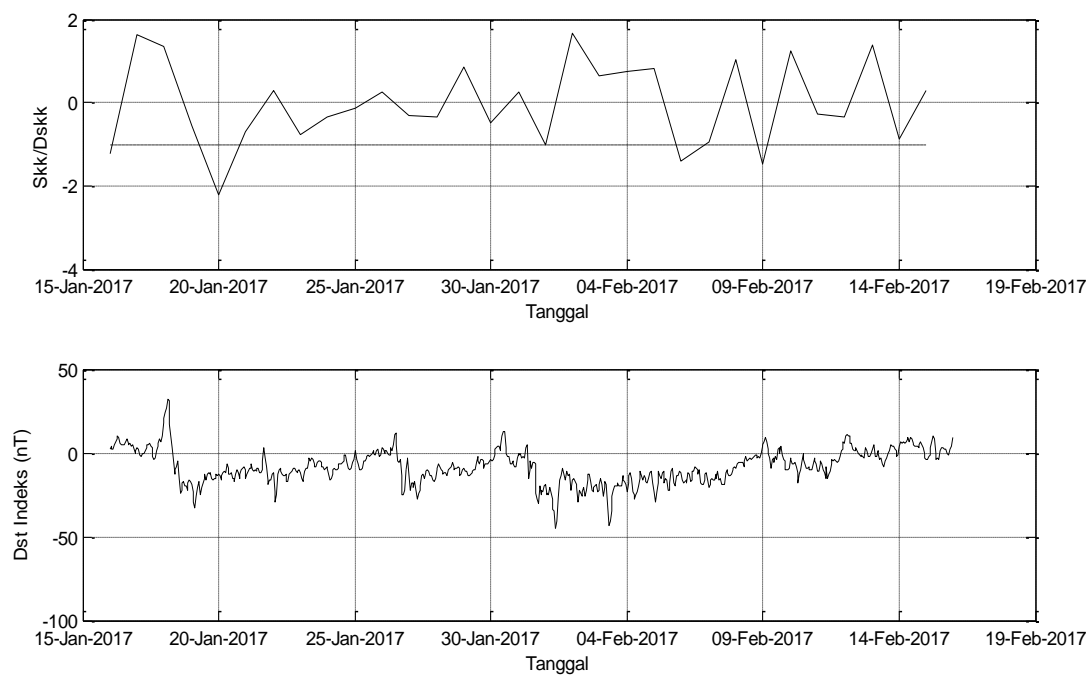

GAMBAR 6. Rasio simpangan koefisien korelasi (Skk) dengan deviasi standar (Dskk) data geomagnet serta indeks Dst sebelum gempa 15 Februari 2017 (M5.2). 

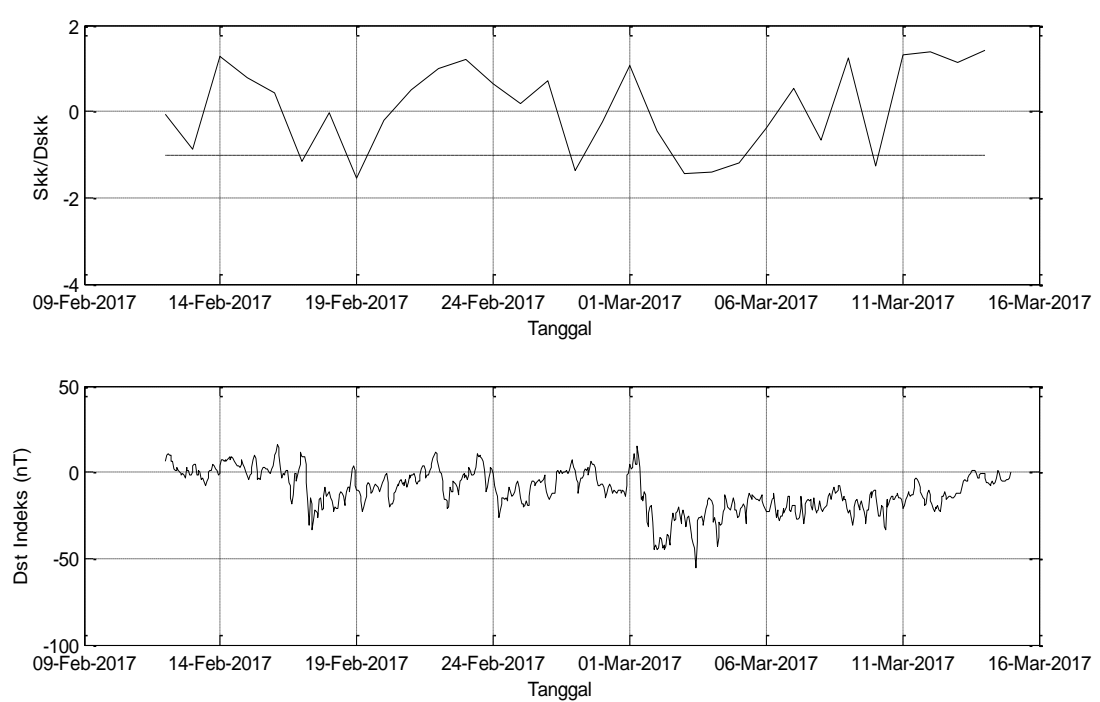

GAMBAR 7. Rasio simpangan koefisien korelasi (Skk) dengan deviasi standar (Dskk) data geomagnet serta indeks Dst sebelum gempa 14 Maret 2017 (M5).

Analisis beberapa kasus gempa di sekitar pelabuhan Ratu memperlihatkan kemunculan anomali geomagnet yang diperkirakan sebagai prekursor gempa. Pada lima kasus gempa yang terjadi dari bulan Januari - Maret 2017 tersebut, secara umum anomali geomagnet yang dapat dipertimbangkan sebagai prekursor gempa terjadi 16 hingga 2 hari sebelum gempa utama terjadi.

\section{KESIMPULAN}

Penerapan metode korelasi polarisasi magnet $\mathrm{Z} / \mathrm{H}$ pada kasus gempa di sekitar Pelabuhan Ratu yang terjadi pada tanggal 12 Januari 2017 (magnitudo 4.8), 26 Januari 2017 (magnitudo 4.8), 8 Februari 2017 (magnitudo 5), 15 Februari 2017 (magnitudo 5.2), dan 14 Maret 2017 (magnitudo 5) menunjukkan kemunculan anomali geomagnet yang dapat dikategorikan sebagai prekursor gempa. Kemunculan anomali geomagnet berkisar antara 16 - 2 hari sebelum gempa terjadi.

\section{UCAPAN TERIMAKASIH}

Penulis mengucapkan terimakasih kepada Pusat Penelitian dan Pengembangan, Badan Meteorologi Klimatologi dan Geofisika (BMKG), atas kesempatan dan fasilitas yang diberikan selama penelitian. Kepada Dr. Buldan Muslim atas segala referensi yang diberikan serta Kepala Bidang dan staf Litbang Geofisika BMKG atas segala diskusi dan saran yang diberikan.

\section{REFERENSI}

[1] M. Hayakawa, O. A. Molchanov, "Seismo Electromagnetics: Lithosphere-Atmosphere Ionosphere Coupling," TERRAPUB, Tokyo, 2002, p 477.

[2] M. Hayakawa, K. Hattori, K. Ohta, "Monitoring of ULF (Ultra Low Frequency) Geomagnetic Variations Associated with Earthquakes," Sensor, 7, 1108 - 1122, 2007.

[3] K. Yumoto, and The MAGDAS Group, "MAGDAS Project and Its Application For Earthquake Prediction," Proceedings of the International Workshop on Integration of Geophysical Parameter as a Set of Large Earthquake Precursors, Bukit Tinggi, 2006. 
[4] M. A. Fenoglio, M. J. S. Johnston, and J. D. Byerlee, "Magnetic and Electric fields associated with changes in high pore pressure in fault zone: Application to the Loma Prieta ULF emission,” J. Geophys.Res., 87 (B9), 12951 - 12958, 1995.

[5] B. Sunardi, Sulastri, "Pemantauan Anomali Total Electron Content (TEC) Berkaitan Dengan Kejadian Gempabumi Di Sekitar Wilayah Jawa Tahun 2015," Spektra, Jurnal Fisika dan Aplikasinya, 1 (2), 1 - 6, 2016.

[6] B. Sunardi, B. Muslim, dan S. Pakpahan, "Anomali Total Electron Content (TEC) Sebelum Gempabumi Kuat di Indonesia Tahun 2014," Prosiding Seminar Nasional Fisika 2015, 378 $-384,2015$.

[7] A. S. Prayogo, dan B. Sunardi, "Tren Anomali Elektromagnetik Sebagai Prekursor Gempabumi Dengan Parameter Terkait di Observatori Pelabuhan Ratu," Natural, 3 (1), 35 43, 2015.

[8] A. S. Prayogo, S. Pakpahan, and B. Sunardi, "Assesment of Electromagnetic and Radon Concentration as Earthquake Precursors," Proceeding of The 5th Annual Basic Science International Conference, 77 - 80, 2015.

[9] B. Sunardi, B. Muslim, D. Ngadmanto, P. Susilanto, J. Nugraha, S. Pakpahan, A. S. Prayogo, Sulastri, "Ionoquake, Sistem Monitoring Data TEC-GPS Untuk Studi Prekursor Gempabumi Di Indonesia," Prosiding Seminar Ilmiah Meteorologi Klimatologi dan Geofisika, 2015.

[10] B. Sunardi, B. Muslim, A. S. Prayogo, S. Pakpahan, D. Ngadmanto, et al., "Penelitian Tentang Prekursor Gempabumi II," Prosiding Seminar Ilmiah Hasil-Hasil Penelitian dan Pengembangan Puslitbang BMKG Tahun 2014, 2015.

[11] B. Muslim, "Pengujian Teknik Korelasi Untuk Deteksi Pengaruh Aktivitas Gempa Bumi Dari Data TEC Ionosfer," Prosiding Seminar Nasional Fisika HFI, 2014.

[12] BMKG. (2017, Apr 10). Earthquake Repository [Online]. Available: http://repo gempa.bmkg.go.id/.

[13] I. P. Dobrovolsky, S. I. Zubkov, and V. I. Miachkin, "Estimation of the size of earthquake preparation zones," Pure and Applied Geophysics, 117 (5), 1979.

[14] World Data Center for Geomagnetism, Kyoto. (2017, Apr 10). Real-time (Quicklook) Dst index [Online]. Available: http://wdc.kugi. kyoto-u.ac.jp/dst_realtime/201702/index.html.

[15] W. D. Gonzales, B. T. Tsurutani, A L. Clua de Gonzales, "Interplanetary origin of magnetic storms," Space Sci. Rev., 88, 1999.

[16] Y. Cerrato, E. Saiz, C. Cid, and M. A. Hidalgo, "Geomagnetic Storms: Their sources and a model to forecast the Dst Index," Astrophysics, 1, 165-176, 2004.

[17] K. Hattori, "Singular Spectral Analysis and Principal Component Analysis for Signal Discrimination of ULF Geomagnetic Data associated with 2000 Izu Island Earthquake Swarm," Physics Chemistry Earth, 2006.

[18] S. Breiner, "Geomagnetic indications of apparent deep crustal deformation," Physics and Chemistry of the Earth, 2006. 